\title{
Drug Resistance Mutations and Genetic Diversity in Patients Treated for HIV Type 1 Infection in Rural Care Centers in Togo
}

\author{
Anoumou Dagnra1 ${ }^{*}$, Abla Konou ${ }^{1}$, Mounerou Salou ${ }^{1}$, Pascal Kodah ${ }^{2}$, Damobé Kombate ${ }^{3}$, \\ Prince David ${ }^{1,2}$ \\ ${ }^{1}$ Université de Lomé, Centre de Biologie Moléculaire et d'Immunologie (BIOLIM/FSS/UL), Lomé, Togo \\ ${ }^{2}$ Centre Médico-Social (CMS) Atakpamé, Atakpamé, Togo \\ ${ }^{3}$ Hopital d'Aného, Aného, Togo \\ Email: ‘a.dagnra@yahoo.fr, ekonou@yahoo.fr, mounerous@gmail.com, marcelin070474@yahoo.fr, \\ tchabia2005@yahoo.fr, mireilleprincedavid@gmail.com
}

Received 21 July 2016; accepted 26 August 2016; published 29 August 2016

Copyright (C 2016 by authors and Scientific Research Publishing Inc.

This work is licensed under the Creative Commons Attribution International License (CC BY).

http://creativecommons.org/licenses/by/4.0/

c) (i) Open Access

\section{Abstract}

Introduction: Access to antiretroviral treatment (ART) in resource-limited countries has increased significantly but scaling up ART into rural areas is more recent and information on treatment outcome in rural areas is still very limited. We reported here virological outcome and drug resistance in ART in rural settings in Togo. Methods: HIV-1 infected adults ( $\geq 18$ years) and infants were enrolled in routine medical visit at 12 on first-line ART in three HIV care centers. Epidemiological and demographic information and data on ART history were collected. Viral load (VL) was determined and genotypic drug resistance testing was performed on all samples with viral load above 1000 copies/ml. Results: 102 adult patients and 27 infants were consecutively enrolled. Virological failure was observed in $28(21.5 \%)$ patients. For $25 / 28$ patients, sequencing was successful and drug resistance mutations were observed in $23(92 \%)$ of them. The global prevalence of drug resistance in the study population was thus at least $17.8 \%(23 / 129)$, with $7(6.9 \%)$ patients infected with HIV strains that are resistant to two of the three first-line antiretroviral (ARVs) drugs and $9(8.3 \%)$ to all three first-line ARVs. As expected, the observed drug resistance mutations were mainly associated with the drugs used in first line regimens, zidovudine, lamivudine and effavirenz/nevirapine but several patients accumulated high numbers of mutations and developed also cross-resistance to abacavir, didanosine or the new non-nucleoside reverse transcriptase inhibitor drugs, like etravirine and rilpivirine. Conclusion: The observations on ART treatment outcome from ART clinics in rural areas are the same as observed in previous observations in Lomé, the capital city. Although access to viral load will improve treatment outcome, bet-

\footnotetext{
"Corresponding author.
}

How to cite this paper: Dagnra, A., Konou, A., Salou, M., Kodah, P., Kombate, D. and David, P. (2016) Drug Resistance Mutations and Genetic Diversity in Patients Treated for HIV Type 1 Infection in Rural Care Centers in Togo. Open Journal of Medical Microbiology, 6, 111-115. http://dx.doi.org/10.4236/ojmm.2016.63015 
ter programme management and implementation of actions to improve factors as patient adherence, drugs stock-outs and lost to follow-up are also essential.

\title{
Keywords
}

\author{
HIV-1, Antiretroviral Treatment, Drug Resistance, Genetic Diversity, Rural, Togo
}

\section{Introduction}

Access to antiretroviral treatment (ART) in sub-Saharan Africa and other resource-limited settings has increased significantly over the last decades thanks to international partners funding HIV treatment programs and local government [1]. The increasing access to ART has significantly improved survival of HIV infected patients and reduced also new HIV infections [2]. Although ART regimens are standardized and patient monitoring is very similar, heterogeneous treatment outcomes have been observed in the national ART programs in different countries; as such virological failure can range from less than 3\% to more than $20 \%$ in patients who are on ART for 12 or 24 months [2]-[4]. These different outcomes most likely depend on ART-programme management. Access to ART was initially mainly concentrated to health structures in capital cities or large urban areas. Scaling up ART into rural settings is more recent and information on treatment outcome in rural settings is still very limited [5]. Moreover, deficiencies in health systems and resources which are more frequent, such as unreliable supply systems, storage and the lack of qualified personnel to prescribe and follow the treatment could create the conditions for accelerated development of HIV resistance to antiretroviral drugs

Togo is a small country of 6,191,000 million inhabitants at 2010, located in West Africa, with an estimated HIV prevalence of around 3\% in the general population [6] [7]. Scaling up of ART started in 2007 in Lomé, the capital city, and in 2014 at least $30 \%$ of HIV infected individuals are receiving ART which corresponds to almost $50 \%$ of them who are in need for ART according to WHO guidelines from 2010 (CD4 count < 350) [8]. However, previous studies showed that a relative high proportion of patients (13\% to $25 \%)$ receiving ART for 12 or 24 months were resistant to at least one drug of their first line regimens [2] [9]. Since 2008, access to ART has been also expanded to rural areas but the outcome has never been evaluated. Here we describe virological outcome and emergence of drug resistance in a cross-sectional study among HIV-1 infected patients treated according to the national guidelines in ART clinics located in five rural settings in Togo.

\section{Methods}

\subsection{Study Sites and Population}

In 2012, a cross-sectional evaluation of treatment outcome was conducted between January and September in three care rural centers that administer antiretroviral (ARV) drugs and monitor treatment according to national recommendations in Togo: Aného, Atakpamé, Kpalimé Those sites are located in south region of Togo (60 to $122 \mathrm{~km}$ distance from Lomé, the capital city).

HIV-1 infected patients were consecutively enrolled when attending healthcare services for their routine medical visit at $12 \pm 2$ months on first-line ART. This study was approved by each participating patient, informed consent was obtained. Questionnaires were used to collect epidemiological and demographic information for each patient, and ART history was collected from on-site medical records. Whole blood was drawn and plasma was separated from cells by centrifugation and three plasma aliquots were stored at $-20^{\circ} \mathrm{C}$ for maximum one week on site and were subsequently transported by road in a cool box to the Laboratoire de Biologie Moléculaire et d'Immunologie (BIOLIM/FSS-UL) where they were stored at $-80^{\circ} \mathrm{C}$ for further HIV-1 RNA quantification and subsequent drug resistance genotyping for patients on virological failure. BIOLIM/FSS-UL is the national reference laboratory of HIV that is integrated in the national program of HIV control Togo.

\subsection{Virological Analyses}

Viral load (VL) was determined using Real Time m2000rt (Abbott Pack, IL, USA) in Lomé (BIOLIM/FSS-UL). Patients with VL $\geq 1000$ copies/ml were considered on virological failure and were subsequently tested for 
genotypic drug resistance. Genotypic drug resistance testing was done in a WHO accredited laboratory (IRD, Montpellier, France). Protease and a 798bp fragment from the Reverse Transcriptase (RT) region was amplified with the in-house protocol from the Agence Nationale de Recherche sur le Sida et les hépatites en France (ANRS), (www.hivfrenchresistance.org/ANRS-procedures.pdf). PCR products were purified and directly sequenced using the Big Dye Terminator v3.1 Cycle Sequencing kit (Applied Biosystems, Carlsbad, CA). Drug resistance mutations (DRM) were identified using the ANRS interpretation algorithms version 24

(http://www.hivfrenchresistance.org/2014/Algo2014.pdf).

\section{Results}

A total of 129 patients were consecutively enrolled. In all sites, more women were enrolled than men; 95/129 (73.6\%) (Table 1). The median age of the patients was 31 (IQR 25 - 36). More than 97\% (125/129) of the patients have been exposed zidovudine (AZT) plus lamivudine (3TC) plus nevirapine (NVP) and/or efavirenz (EFV). None of the patients received other reverse transcriptase inhibitors (RTI) than described above or protease inhibitors (PI). At ART initiation the overall median CD4 count $/ \mathrm{mm}^{3}$ was 185 (IQR 86 - 261) for the patients who started ART $12 \pm 2$ months earlier. Overall, 73/129 (56.3\%) and 56/129 (43.5\%) of the patients were in WHO stages 1 or 2 and WHO stages 3 or 4 , respectively.

Overall, 28 (21.5\%) patients had VL $>1000$ copies $/ \mathrm{ml}$. The median viral load in these 28 patients was 25,000 copies/ml (IQR 7100 to 55,000 copies $/ \mathrm{ml}$ ). Virological failure was heterogeneous across the different sites and ranged from $15.1 \%$ to $25 \%$, but this could be related to the relatively low numbers of patients included per site. For $25(89.2 \%)$ of the 28 patients, sequencing was successful and drug resistance mutations were observed in 23 (92\%) of them. Among the 23 drug resistant HIV strains, 19 were resistant to NRTIs and NNRTIs, one to NRTIs only and three to NNRTIs only. No drug resistance to protease inhibitors was observed. Of the NRTI-associated DRMs, M184V selected by 3TC was the most frequent NRTI mutation (86.2\%). Frequently observed TAMs included M41L, D67N/D, K70R, K219E/Q and T215Y/F. The K65R mutation was seen in two patients, none received TDF. One third of the patients had at least 3 or more NRTI mutations and several patients were already predicted to be resistant to Abacavir $(\mathrm{ABC})(\mathrm{n}=7)$, didanosine (DDI) $(\mathrm{n}=2)$ or TDF $(\mathrm{n}=3)$. Among NNRTI mutations, $\mathrm{Y} 181 \mathrm{C} / \mathrm{Y}$ and $\mathrm{K} 103 \mathrm{~N}$ were most frequently observed and $23.1 \%$ of patients accumulated at least three NNRTI mutations, with $21.5 \%$ and $67.7 \%$ that were predicted to be resistant to etravirine (ETV) and rilpivirine (RPV) second line NNRTIs, respectively.

Overall, CRF02_AG predominate and represent 11/23 (47.8\%) of the strains. The other variants are in decreasing order of importance: recombinant CRF06_cpx $(n=4,17.3 \%)$, subtype $\mathrm{G}(\mathrm{n}=2,8.7 \%)$, sub-subtype A3 $(\mathrm{n}=1,4.3 \%)$ and subtype $\mathrm{C}(\mathrm{n}=1,4.3 \%)$. The remaining $4(17.4 \%)$ strains could not be classified at all with a known subtype or CRF and represent each a different unique recombinant (URF).

\section{Discussion}

This study reported the first data in rural setting about HIV treatment. Overall, we showed that $17.8 \%$ (Table 1) of patients were on virological failure and almost all of them (89.2\%) were infected with drug resistant HIV-1 strains. The observations from ART clinics in rural areas in 2014 are closed to what has been observed in

Table 1. Characteristics of patients with 12 months ART experience.

\begin{tabular}{|c|c|c|c|c|c|}
\hline \multicolumn{2}{|c|}{ Paramètres } & $\begin{array}{l}\text { Aného } \\
\mathrm{n}=28\end{array}$ & $\begin{array}{c}\text { Kpalimé } \\
\mathrm{n}=45\end{array}$ & $\begin{array}{c}\text { Atakpamé } \\
\mathrm{n}=56\end{array}$ & Total \\
\hline & & \multicolumn{4}{|c|}{ Number (\%) } \\
\hline \multicolumn{2}{|c|}{ Women } & $22(78.5)$ & $38(84.4)$ & $35(62.5)$ & $95(72.6)$ \\
\hline \multirow[t]{2}{*}{ WHO stages } & $1 / 2$ & $13(46.4)$ & $29(53.3)$ & $30(53.5)$ & $73(56.5)$ \\
\hline & $3 / 4$ & $15(53.6)$ & $16(46.7)$ & $26(46.5)$ & $56(43.5)$ \\
\hline \multicolumn{2}{|c|}{ CD4 counts available at baseline } & $26(92.8)$ & $45(100)$ & $56(100)$ & $127(98.4)$ \\
\hline \multicolumn{2}{|c|}{ Median CD4 counts at baseline (IQR) } & $160(91-181)$ & $180(100-235)$ & $197(111-277)$ & $185(86-261)$ \\
\hline \multicolumn{2}{|c|}{$\mathrm{VL}>1000$ copies $/ \mathrm{ml} \mathrm{n}()$} & $7(25)$ & $7(15.5)$ & $14(25)$ & $28(21.7)$ \\
\hline
\end{tabular}


previous studies from Lomé, the capital city; for example in a survey conducted about one year earlier in 2010/2011, 19\% (124/642) of patients for 12 or 24 months on ART were infected with HIV drug resistant strains [2]. Whereas numerous reports are available on treatment outcome of HIV infected patients on ART according to the WHO public health approach in urban settings from different sub-Saharan countries, only very few studies reported observations from rural areas [2] [9]-[11]. A study conducted in rural district hospitals in Cameroon at a 50 to $150 \mathrm{~km}$ distance from Yaoundé, the capital city, 10\% of patients were infected with drug resistant HIV strains after a median of 12 months on ART [12] which is close to rates observed in Yaoundé [3]. Another study conducted in Senegal, Mali, and Guinea, showed equal proportions of drug resistance in urban and rural areas which varied from $9.2 \%$ to $15.9 \%$ after a median of 36 months on ART [13].

Overall it seems that treatment outcome varies among countries, but within countries treatment outcome in rural settings are very similar to those in urban settings, except in extreme conditions. These observations are in line with the fact that national ART-programme management plays a role in treatment outcome in resource-limited countries [2]. Although it has to be noted that our studies and many of the above mentioned studies are not representative of overall outcome of ART in rural settings.

As expected the observed drug resistance mutations were mainly associated with the drugs used in first line regimens, AZT/d4T and/or 3TC and/or EFV/NVP. Of the NRTI-associated DRMs, M184V selected by 3TC was the most frequent NRTI mutation, (88.1\%). Frequently observed TAMs included M41L, D67N/D, K70R, K219E/Q and T215Y/F. The K65R mutation was seen in two patients. However, in the absence of biological monitoring in resource-limited countries, treatment failures are detected too late and patients continue their treatment even if it is failing and accumulate high numbers of mutations [2] [13]-[15]. Like in other reports on treatment outcome, several patients in our survey accumulated also high numbers of mutations and developed also cross-resistance to abacavir (ABC), didanosine (DDI) or the new NNRTI drugs like etravirine (ETR) and rilpivirine (RPV) thus compromising these drugs for second- and/or third-line treatment. Among NNRTI mutations, $\mathrm{Y} 181 \mathrm{C} / \mathrm{Y}$ and $\mathrm{K} 103 \mathrm{~N}$ were most frequently observed.

Globally, the HIV-1 subtypes and CRFs which we documented here, are concordant with previous reports on HIV-1 variants circulating in Togo and neighbouring countries where CRF02_AG, CRF06_cpx and subtype G are the most common variants [9] [16]-[19]. CRF02_AG, which is the major variant in West Africa, accounted for approximately 50\% in Togo, which is lower than in some other West African countries [17]-[19].

\section{Conclusion}

The observations on ART treatment outcome from ART clinics in rural settings are close to observations in Lomé, the capital city. The expansion of ART in Togo still represents a challenge and ART outcome still needs to be improved. Although access to viral load will improve treatment outcome, better programme management and implementation of actions to improve factors as patient adherence, drugs stock-outs and lost to follow-up are also essential.

\section{Acknowledgements}

We thank Nicole Vidal for technical assistance.

Our sincere thanks to the BIOLIM/FSS/UL laboratory Team in particular to Mr Ouro-Medeli Alassane, Mrs Ehlan-Amenya Phyllis and Mr Ali-Edje Komlan.

\section{Conflict of Interest}

The authors declare no conflict of interest.

\section{Funding}

This study was funded by Global Fund round 8, Institut de Recherche pour le Développement IRD and The French Cooperation in Togo.

\section{References}

[1] Mutevedzi, P.C. and Newell, M.L. (2014) The Changing Face of the HIV Epidemic in Sub-Saharan Africa. Tropical 
Medicine and International Health, 19, 1015-1028. http://dx.doi.org/10.1111/tmi.12344

[2] Aghokeng, A.F., Monleau, M., Eymard-Duvernay, S., Dagnra, A., Dramane, K., Ngo-Giang, N., et al. (2014) Extraordinary Heterogeneity of Virological Outcomes in Patients Receiving Highly Antiretroviral Therapy and Monitored with the World Health Organization Public Health Approach in Sub-Saharan Africa and Southeast Asia. Clinical Infectious Diseases, 58, 99-109. http://dx.doi.org/10.1093/cid/cit627

[3] Rusine, J., Asiimwe-Kateera, B., Van de Wijgert, J., Boer, K.R., Mukantwali, E., Karita, E., et al. (2013) Low Primary and Secondary HIV Drug-Resistance after 12 Months of Antiretroviral Therapy in Human Immune-Deficiency Virus Type 1 (HIV-1) Infected Individuals from Kigali, Rwanda. PLoS One, 8, e64345.

http://dx.doi.org/10.1371/journal.pone.0064345

[4] Wadonda-Kabondo, N., Hedt, B.L., Van Oosterhout, J.J., Moyo, K., Limbambala, E., Bello, G., et al. (2012) A Retrospective Survey of HIV Drug Resistance among Patients 1 Year after Initiation of Antiretroviral Therapy at 4 Clinics in Malawi. Clinical Infectious Diseases, 54, 355-361. http://dx.doi.org/10.1093/cid/cis004

[5] Semwanga, D., Nsubuga, R.N., Mayanja, B.N., Lyagoba, F., Magambo, B., Yirrel, D., et al. (2013) Effect of HIV-1 Subtypes on Disease Progression in Rural Uganda: A Prospective Clinical Cohort Study. PloS One, 8, e71768. http://dx.doi.org/10.1371/journal.pone.0071768

[6] Institut national de la statistiqueet des étudeséconomiques et démographiques (2010) http://www.stat-togo.org/nada/index.php/catalog/2

[7] UNAIDS Report on Global AIDS (2013) http://www.unaids.org/fr/dataanalysis/knowyourresponse/countryprogressreports/2014countries

[8] WHO (2010) Antiretroviral Therapy for HIV Infection in Adults and Adolescents: Recommendations for a Public Health Approach. http://www.who.int/hiv/pub/arv/adult2010/en/index.html

[9] Dagnra, A.Y., Vidal, N., Mensah, A., Patassi, A., Aho, K., Salou, M., et al. (2011) High Prevalence of HIV-1 Drug Resistance among Patients on First-Line Antiretroviral Treatment in Lomé, Togo. Journal of the International AIDS Society, 14, 30. http://dx.doi.org/10.1186/1758-2652-14-30

[10] Hamers, R.L., Oyomopito, R., Kityo, C., Phanuphak, P., Siwale, M., Sungkanuparph, S., et al. (2012) Cohort Profile: the PharmAccess African (PASER-M) and the TREAT Asia (TASER-M) Monitoring Studies to Evaluate ResistanceHIV Drug Resistance in Sub-Saharan Africa and the Asia-Pacific. International Journal of Epidemiology, 41, 43-54. http://dx.doi.org/10.1093/ije/dyq192

[11] Barth, R.E., Tempelman, H.A., Moraba, R. and Hoepelman, A.I. (2011) Long-Term Outcome of an HIV-Treatment Programme in Rural Africa: Viral Suppression despite Early Mortality. AIDS Research and Treatment, 2011, 43-75. http://dx.doi.org/10.1155/2011/434375

[12] Boullé, C., Kouanfack, C., Laborde-Balen, G., Aghokeng, A.F., Boyer, S., Carrieri, M.P., et al. (2013) Prediction of HIV Drug Resistance Based on Virologic, Immunologic, Clinical, and/or Adherence Criteria in the Stratall ANRS 12110/ESTHER Trial in Cameroon. Clinical Infectious Diseases, 57, 604-607. http://dx.doi.org/10.1093/cid/cit323

[13] Fofana, D.B., Soulié, C., Baldé, A., Lambert-Niclot, S., Sylla, M., Ait-Arkoub, Z., et al. (2014) High Level of HIV-1 Resistance in Patients Failing Long-Term First-Line Antiretroviral Therapy in Mali. Journal of Antimicrobial Chemotherapy, 69, 2531-2535. http://dx.doi.org/10.1093/jac/dku153

[14] Fall-Malick, F.Z., Tchiakpe, E., Ould Soufian, E.S., Diop-Ndiaye, H., Mouhamedoune, B.A., Ould Horma, B.A., et al. (2014) Drug Resistance Mutations and Genetic Diversity in Adults Treated for HIV Type 1 Infection in Mauritania. Journal of Medical Virology, 86, 404-410. http://dx.doi.org/10.1002/jmv.23860

[15] Wallis, C.L., Aga, E., Ribaudo, H., Saravanan, S., Norton, M., Stevens, W., et al. (2014) Drug Susceptibility and Resistance Mutations after First-Line Failure in Resource Limited Settings. Clinical Infectious Diseases, 59, 706-715. http://dx.doi.org/10.1093/cid/ciu314

[16] Yaotsè, D.A., Nicole, V., Roch, N.F., Mireille, P.D., Eric, D. and Martine, P. (2009) Genetic Characterization of HIV-1 Strains in Togo Reveals a High Genetic Complexity and Genotypic Drug-Resistance Mutations in ARV Naive Patients. Infection, Genetics and Evolution, 9, 646-652. http://dx.doi.org/10.1016/j.meegid.2009.04.002

[17] Delgado, E., Ampofo, W.K., Sierra, M., Torpey, K., Pérez-Alvarez, L., Bonney, E.Y., et al. (2008) High Prevalence of Unique Recombinant Forms of HIV-1 in Ghana: Molecular Epidemiology from an Antiretroviral Resistance Study. Journal of Acquired Immune Deficiency Syndromes, 48, 599-606. http://dx.doi.org/10.1097/QAI.0b013e3181806c0e

[18] Derache, A., Maiga, A.I., Traore, O., Akonde, A., Cisse, M., et al. (2008) Evolution of Genetic Diversity and Drug Resistance Mutations in HIV-1 among Untreated Patients from Mali between 2005 and 2006. Journal of Antimicrobial Chemotherapy, 62, 456-463. http://dx.doi.org/10.1093/jac/dkn234

[19] Tebit, D.M., Ganame, J., Sathiandee, K., Nagabila, Y., Coulibaly, B. and Krausslich, H.G. (2006) Diversity of HIV in Rural Burkina Faso. Journal of Acquired Immune Deficiency Syndromes, 43, 144-152. http://dx.doi.org/10.1097/01.qai.0000228148.40539.d3 


\section{Submit or recommend next manuscript to SCIRP and we will provide best service for you:}

Accepting pre-submission inquiries through Email, Facebook, LinkedIn, Twitter, etc.

A wide selection of journals (inclusive of 9 subjects, more than 200 journals)

Providing 24-hour high-quality service

User-friendly online submission system

Fair and swift peer-review system

Efficient typesetting and proofreading procedure

Display of the result of downloads and visits, as well as the number of cited articles

Maximum dissemination of your research work

Submit your manuscript at: http://papersubmission.scirp.org/ 